\title{
IMAGINING THE PAST; REMEMBERING THE FUTURE
}

\author{
JERRY MASHAW*
}

When writing a short Comment on two long Articles it is difficult to be both substantive and pohte. The available space inust be devoted largely to points of disagreement, not to the authors' many fine arguments and insights. I therefore urge the reader to remember that this commentary lacks balance. My admiration for the projects that Chris Edley and Cass Sunstein have begun-projects that contemplate the dismantling and reconstruction of American administrative law-will take a back seat to my concerus about the current directions of their particular enterprises.

At its most general level my critique is captured in the title of this Comment. In my view, Edley and Sunstein imagine the past of administrative law that represents but a partial understanding of where we have been and where we have come. They then propose a future that is, I fear, made up primarily of the recollection and extension of reforms that have already becn attempted. Thus, their arguments have modest capacities, if applied generally, to do more good than harm. ${ }^{1}$

\section{The Edley Challenge}

According to Chris Edley, the administrative state has failed. He describes a polity beset by maladies ranging from lomelessness and crack-babies to the savings and loan debacle and the crisis of Third World debt. ${ }^{2}$ Americans, in his view, are being denied "sound governance": the sort of activist, imaginative governance that would solve those probleins, and many more like them. ${ }^{3}$

- Gordon Bradford Tweedy Professor of Law and Organization, Yale Law School.

1. As contemplated by the organizers of this symposium, Edley and Sunstein have produced papers that rehearse and elaborate the arguments in their recent books. See C. EDLEY, ADMINISTRATIVE LAW: RETHINKING JUdiCial CONTROL OF BUREAUCRACY (1990); C. SUNSTEIN, AFTER THE RIGHTS REVOLUTION: RECONCEIVING THE REGULATORY STATE (1990). I trust that a commentator will be forgiven if his comments are similarly often drawn from a recent book. See J. Mashaw \& D. Harfst, The Struggle for Auto SAfety (1990).

2. See Edley, The Governance Crisis, Legal Theory, and Political Ideology, 1991 DukE L.J. $561,563.65$.

3. See id. at $566-67$. 
Strangely enough, Edley blames many of these late-twentieth-century ills on the "antidiscretion project" of American administrative law. ${ }^{4}$ Stranger yet, Edley sees the culprit to be the defective conceptualization of this project as it is played out in administrative law doctrine, that is, in the principles enunciated and applied by the judiciary when reviewing administrative action. ${ }^{5}$ Specifically, he suggests that the problems with administrative law doctrine fall into two categories. First, administrative law's conceptualizations are built on what Edley describes as "eighteenth-century sensibilities"; in particular, a contimuing commitment to the separation of powers. ${ }^{6}$ Second, these ideas are beset by nornative dualities and boundary problems that make thein hopelessly indeterminate. ${ }^{7}$ The work of the courts in developing and applying doctrine thus exhibits a pervasive character of "ambivalence and inconsistency."8

As I understand Edley's argument, the solution to our multiple ills lies in breaking out of the symbolic shackles of the eighteenth-century separation of powers mindset. The escape from this intellectual bondage will occur when courts recognize that they are, like other governmental institutions, firmly embedded in pohtics. If these newly politicized courts then adopt an appropriate ideology of governance-one that emphasizes transformation and fluidity, participation and engagement, and skepticisin toward any stable set of institutional arrangements-then we will be on the way to solving the current governance crisis.

Edley suminarizes this vision of the future $\mathrm{m}$ a few ringing lines:

Administrative law can be part of the developing critique and renovation of governance, but only if it abandons its implicit antidiscretion project. That projeet embodies tension between two elements. One is the affirmative goal of strengthening the administrative state by, for example, promotimg the integration of expertise into bureaucratic action. The other is the imitation of separation of powers formalism, with the trichotomy of decisionmaking paradigms [adjudicatory fairness, science, and politics] as a sort of second-best structural strategy to protect us against arbitrary discretion and official ambition.

Instead, imagime that the core of administrative law can be com1mitted to an ongoing exchange with the political branches about norms of sound governance. I imagine a process of subconstitutional, common law elaboration of substantive and procedural matters ranging from cost-benefit methodology, to the paper hearing requirements in informal rulemaking, to presumptions about the direction of congres-

4. See id. at 566 .

5. See id. at 566-67. I will later return to the question of exactly how defective legal concepts come to be so implicated in the concrete ills of American (and even international) society. For now we will note only the alleged defects in administrative law's intellectual arsenal.

6. See id. at 567.

7. See id. at $\mathbf{5 7 0 .}$

8. Id. at 574 . 
sional policies trenching on such fundamental social concerns as federalism and income redistribution.

The new administrative law would have no place for such cases as Chevron, Vermont Yankee, or last term's decision in Pension Benefit Guarantee Corp. v. LTV Corp. ${ }^{9}$

I must confess that I find these paragraphs deeply puzzling. A critique of the Edley project requires three interconnected imquiries. First, we must try to understand clearly his complaint against administrative law. Second, we must try to understand how that complaint maps on to the doctrine of administrative law that he would abandon. Finally, we must try to inagine how a revised ideology would generate a revised administrative law doctrine that would promote the goals that Edley espouses, or at least proniote those goals better than the existing doctrine that he rejects.

Given his critique of separation of powers thinking, Edley's desire to cast away Chevron ${ }^{10}$ and Vermont Yankee ${ }^{11}$ comes as a real surprise. I am hard-pressed to think of two decisions that are better exainples of the abandonment of those doctrinal fornulations against which Edley levels his critique. On my cheerful interpretation of its meaning, Chevron candidly rejects two conventional tenets of separation of powers formalism: First, that Congress decides all policy questions (or should); ${ }^{12}$ and, second, that courts decide all questions of law, mcluding questions of statutory interpretation. ${ }^{13}$ Chevron straightforwardly admits that Congress can delegate important policy choices to an Environmental Protection Agency (EPA) administrator, that administrations are in politics, mcluding electoral politics, and that agencies carrying out administrative duties are given a policy choice that is both connected to presidential politics and legitimized by it. ${ }^{14}$ This recognition of the political connectedness of administration is then combined with the recognition that statutory interpretation includes policy choice. Statutory imterpretation inay, therefore, be appropriately allocated to politico-administrative institutions, subject only to very loose judicial review.

In some ways it is hard to imagine a case that better exemplifies the rejection of "formalist" separation of powers categorizations of the conventional sort, i.e., legislators enact the law, judges interpret the law, and administrators execute the law. In addition, Chevron seems to proinote two more of Edley's goals: (1) "the integration of expertise into bureau-

9. Id. at 601 (footnotes omitted).

10. Chevron U.S.A., Inc. v. Natural Resources Defense Council, Inc., 467 U.S. 837 (1984).

11. Vermont Yankee Nuclear Power Corp. v. Natural Resources Defense Council, Inc., 435 U.S. 519 (1978).

12. See Chevron, 467 U.S. at 865 .

13. See id. at 863-64.

14. See id. at 865-66. 
cratic action" and (2) "an ongoing exchange with the political branches about norms of sound governance."15 Indeed, the EPA decision under review in Chevron so combined technical expertise with judgments about techniques of sound governance that the line between the two virtually disappeared. ${ }^{16}$

A similar story can be told about Vermont Yankee. That case quintessentially legitimatizes the authority of agencies to experiment with procedural techniques that are short of trial-type adjudication. The Supreine Court in Vermont Yankee approved an elaborate and unique governance structure for nuclear plant licensing that fit no pre-deterimned mold based on administrative law's so-called "trichotoniy." 17 Moreover, in Baltimore Gas \& Elec. Co. v. Natural Resources Defense Council, Inc., 18 the Court looked carefully at the question of governance that was embedded in the substantive dispute about the potential costs of nuclear waste disposal ${ }^{19}$ and approved an approach to evaluating environnental impacts that focused political responsibility at the national level. ${ }^{20}$ In so doing, the Court elaborated a "subconstitutional, coinınon law" that went directly to the nistitutional or governance issues surrounding cost-benefit or risk-benefit evaluation. ${ }^{21}$ The Court thus made a clear (albeit surely contestable) stateinent concerning "sound governance."

Indeed, as I think about Edley's call for the courts to develop "presumptions" concerning "the direction of congressional policies trenching on such fundamental social concerns as federalisin,"22 I can hardly avoid noting that the Supreine Court seenis to be doing just that, both in its eleventh amendment jurisprudence ${ }^{23}$ and in its interpretations of the reach of federal grant-in-aid statutes. ${ }^{24}$ In addition, one of the strongest lines of "presuinptive" statutory interpretation that has been developed

15. Edley, supra note 2, at 601 .

16. The case was, after all, concerned with a highly complex air quality regulation that involved both new environmental criteria and a new institutional policy that married existing command-andcontrol methodologies of regulatory action to market-like structures for allocating regulatory costs.

17. Vermont Yankee, 435 U.S. at 526. The term "trichotomy" is Edley's. See Edley, supra note 2, at 568-69.

18. 462 U.S. 87 (1983).

19. Id. at $89-90$.

20. Id. at 105.

21. Edley, supre note 2, at 601 .

22. Id.

23. See, e.g., Atascadero State Hosp. v. Scanlon, 473 U.S. 234, 237-47 (1985) (giving a series of constitutional reasons to require the clearest possible expression of congressional intention to abrogate state sovereign immunity).

24. See, e.g., Pennhurst State School \& Hosp. v. Halderman, 451 U.S. 1, 17-18 (1981) (requiring a clear congressional intent to impose financial obligations on states with respect to mental institutions). 
over the last decade involves another of the Court's "sound governance" projects-the avoidance of fragmented interpretative and enforcennent jurisdictions in the implementation of comprehensive scheines of federal administrative regulation. ${ }^{25}$

If Edley is unhappy with these developments, it seems clear that his unhappiness flows froin the results of the cases, not from their mattention to the categories of concerns with which he is interested. Moreover, there is a common feature to the jurisprudence that has been discussed: In every case the activities of the courts have withdrawn judicial jurisdiction in favor of administrative jurisdiction. The real complaint here seems to be one concerning judicial restraint. But that merely restates the problem. Why should an author who favors energetic, activist, and imaginative governance be concerned about judicial restraint in the face of governmental imitiatives?

Three explanations come quickly to mind: pohitics, conceptualism, and optimism. The political explanation I will quickly put aside as inappropriate to serious academic discussion. The liberal, Deinocratic vision of state activism has not been furthered by the congressional-presidential political partnerships of the past two decades. If one's real concern is with "jump-starting" national governance, perhaps one might fall back on the courts as the last resort to provide the juice to "get the country moving again." But if so, we would still need to know why that project seems feasible, a topic to which we will return under the leading of "optimism."

A inore interesting explanation is that Edley is so convinced of the defectiveness of administrative law's conceptual apparatus that he equates conceptual-doctrinal reform with governmental efficacy. There is evidence in his article that would support this explanation. Much of Edley's discussion focuses on the ainbivalence and incolierence ("normative duality" and "contradictions") of legal doctrime. ${ }^{26}$ Yet, although one 1might agree with inuch of this discussion as a descriptive matter, the linkage between conceptual confusion and practical political malfunctioning is left unexplained.

Indeed, given Edley's description, this causal connection is decidedly peculiar. On the one hand, administrative law doctrine is so anbivalent and confused that it is thoroughly ineffective-even in its supposed major project of controlling administrative discretion. Yet, somehow, this same confused, ambivalent, and ineffective doctrine is to be credited

25. See, e.g., Middlesex County Sewerage Auth. v. National Sea Clammers Ass'n, 453 U.S. 1, 11 (1981) (excluding both imphed private rights of actions and $\S 1983$ actions where federal statutes comprehensively regulate a field).

26. See Edley, supra note 2, at 570; C. EDLEY, supra note 1, at 83-86. 
with the destruction of sound governance, and with the various social ills paraded at the beginning of the piece. ${ }^{27}$ How can adıninistrative law doctrine be ineffectual in restraining the exercise of official discretion and simultaneously be the cause of ineffectual governance?

One possible explanation is Edley's apparent belief that effective governinental arrangeinents must establish decision processes that permit a straightforward ratio-deductive explanation of all decisionmaking in terms of the law's ostensibly guiding political ideology. ${ }^{28}$ In this view, cross-cutting pohtical purposes, "balancing" and "tradeoffs" among multiple values, along with compromised institutional structures, are simply the hallmarks of bad government. As I have argued elsewhere, this is a straightforward (if distressingly common) category mistake. ${ }^{29}$ There is no necessary relationship between conceptual coherence and governmental efficacy. Once it is admitted that human values are multiple and that resources are scarce, conflicts amongst goals are inevitable. When one adds to this the recognition that values or aims are abstractly held, but must be concretely applied, there is simply no technique of legal decisionmaking that can avoid either the repeated confrontation of problems of vagneness or the competition annong goals near the boundaries of their relevant apphications.

As one looks at the goals stated by Edley for his revised political ideology, one wonders how he imaguies these values to be applied without stress, or even contradiction. The suggestion, for example, that we should prefer transformation and fluidity, combined with participation and engageinent, ${ }^{30}$ yields an obvious conundrum. How is a set of legal rules or institutions that promotes transformation and fluidity ineant to attract the participation and engagement of those who prefer stability and hierarchy? Competition between these aims is inevitable.

Moreover, I have difficulty envisioning practical legal decisionmaking that does not find Edley's assertion that the injunction to prefer these values should be preferred vague almost to the point of emptiness. Does a preference for transforination and fluidity inean that we are to eschew all structures that establish stability and hierarchy? If so, would this preference include those structures that empower those who promote the aims of transfornation and fluidity? If not, what do the "rights" asserted before these newly activist courts look like? To put the matter in political rather than judicial terıns, might not the requirements of par-

27. See Edley, supra note 2, at 564-65.

28. See id. at 578-95.

29. See T. MARMor, J. Mashaw \& P. Harvey, America's Misunderstood Welfare STATE 222-28 (1990).

30. See Edley, supra note 2, at 594-95. 
ticipation or engagement entail a sense of accomplishment, that is, the creation of enduring or quasi-enduring political results-structures or decisions whose persistence would tlen discourage furtler participation and engagement aimed at fluidity and transformation?

Examples of this sort are abundant, but the point is straightforward and general. Any attempt to realize concretely the values that Edley affirms will reveal a lost of potential contradictions. Pursuit of those goals will necessarily be compromised and uncertain; any attempt at implementation will be subject to the critique that it reveals a shifting and uncertain understanding of what these goals entail. Indeed, charges of contradiction or, at least ambivalence, may cut much deeper because values like participation and engagement contain their own "internal" contradictions. They are simultaneously costs and benefits. How they will be valued by any particular person or group shifts witl time, issue, and other relevant circumstances. And, if the sign to be given these values is either plus or minus depending on context, then the critics will be quick to point out, as Edley does witl the current doctrine, ${ }^{31}$ that we seem not to have any guiding ideology of decisionmaking at all. Thus, if the critique of admimstrative law's current efficacy is a critique based largely on conceptual imcolierence, as it often seems to be in Edley's article, I find myself unsympathetic to the message. This argument treats ubiquitous aspects of the human condition-our ambivalence in the face of competing values and the practical conundra attending the implementation of any abstract goal- -as if they would disappear if we could just straighten out our values and institutions.

But Edley's point may be a different one. He may not really beheve that the values lie espouses can escape vagueness, competition, and contradictions. His point inay be only that we are currently espousing the wrong values, and that a different set, although generating their own normative dualities and contradictions in application, would nevertheless have different concrete effects on governance. If so, I think that Edley escapes conceptualism only at the cost of unjustified optimism.

As I understand his program, Edley imagines that a revitalized and correctly politicized judiciary will stimulate and guide administrative law's "sound governance project." This is wislful thinking at two levels. First, it assumes a transformation of the judiciary from a brake into an accelerator by thrusting the judiciary imto political decisionmaking-a transformation that is spectacularly unlikely given our political traditions. Second, even if this institutional transformation were to take place, Edley's vision furtlier presumes a judiciary that is, to use Bob

31. See id. at 575 . 
Cover's terms, primarily jurisgenerative rather than jurispathic. ${ }^{32}$ I fiud very little in the past of administrative law, at least as developed through judicial review, that supports such a view. And, although we might transcend our experience, Edley offers no innovative techniques to accomphsh this. I will now unpack these two different levels of unjustified optimism.

First, Edley muagines a judiciary that is committed to the primary goals of transformation and fluidity and that unsettles questions rather than settling them. In sliort, courts are goads to further action-constant kibitzers, whose forays into one or another administrative domaim are carried out under the bamier of an activist, but otherwise unspecified, reform agenda. Edley's judiciary breaks down hierarcliy, unsettles stability, exhorts participation, and is highly skeptical of any stable institutional arrangeinents. Such an institutional role for the judiciary is surely a transformative idea. It is a role, lowever, that judges have seldom played in American legal life. And, when played by judges, it is a role that is almost always miniediately re-cast, if not written completely out of the script. Tort law, particularly the developinent of products liability, nay be the best twentieth-century example of a sustained judicial activism that, over half a century, reorganized a major field. But even here we should recognize that judicial "creativity" was largely a reaction to social and economic reorganizations that both pressured existing doctrime and provided the intellectual underpinnings for doctrinal revision. Technological and social change propelled the law. But as David Harfst and I have recently recounted in reviewing the listory of automobile safety law, a truly new idea, that law should force technology, was beyond the judiciary's reach. ${ }^{33}$ Thus, even the sustained judicial creativity that recast the law of products liability evidenced judicial support for fluidity and transformation of a very tepid sort. And, as seems customary when American courts are activist, these developments have generated dramatic political reaction to control the so-called products liability "crisis." 34

When one turns directly to administrative law, the inherently conservative caste of judicial decisionmaking is thrown into even sharper relief. The inajor post-New Deal innovation in adıninistrative procedure has been in what Edley identifies as the "paper hearing" process for ad-

32. See Cover, Foreword: Nomos and Narrative, 97 HARv. L. Rev. 4, 11-44 (1983).

33. See J. MASHAW \& D. HARFST, supra note 1, at 39-46.

34. See, e.g., Margolick, Address by Quayle on Justice Proposals Irks Bar Association, N.Y. Times, Aug. 14, 1991, at A1, col. 2 (reporting speech by Vice President Quayle that argued that the United States is too litigious and has too many excessive damage awards, resulting in a competitive disadvantage for the United States in the world economy). 
ministrative rules. ${ }^{35}$ But here I beheve Edley's image of the recent past of administrative law is deeply problematic. The paper-hearing innovation was largely of congressional and administrative creation, beginning with the National Traffic and Motor Vehicle Safety Act of 1966 (MVSA). ${ }^{36}$ From that moment forward Congress and agencies innovated while the courts struggled to keep up. In so doing, the courts developed a proceduralized rationality review that reinforced the participatory and reason-giving requirements of congressional statutes and administrative regulations. Yet, as Harfst and I again argue, these developments were both profoundly reactive jurisprudentially and immensely destructive for regulatory innovation. ${ }^{37}$

Thus, although I agree that the common law elaboration of "paper hearing" requirements to which Edley refers is probably the most "transformative" activity of the judiciary $m$ administrative law over the past several decades, it hardly evidences the swashbuckling reformative impulses that Edley's prograin demands. That history shows instead that the imtellectual resources upon which judges draw are deeply embedded in a legal culture that is definitional for the judiciary as a legal imstitution. Judicial "transformations" are but attempts to integrate new or truly transformative events into that pre-existing culture. I see no reason to believe that judges will (or should) be willing, or indeed able, to step outside the legal culture to take on a new and truly creative or activist role. To think that they will seems to imagine a past for administrative law that never was. ${ }^{38}$ Judges have not transformed rulemaking over the past twenty-five years; they have mstead reshaped it to fit within the preexisting vision of the judicial role and the rule of law. This is a deeply conservative, not a jurisgenerative, enterprise.

Edley's over-optimism about recreating the legal culture is combined with a second equally unfounded optimism - the effects of judicial activism on policy development. Harfst and I conclude, for exainple, that judicial "creativity" im "proceduralizmg" regulatory decisionmaking concerning motor vehicle safety hardly invigorates that enterprise, but instead bears a substantial portion of the blame for the lethargy and imeffectiveness of that potential transformative (indeed, intellectually revolutionary) regulatory scheme. ${ }^{39}$ Shep Melmick makes similar findings

35. See Edley, supra note 2, at 601.

36. 15 U.S.C. $\S \S 1381-1431$ (1988).

37. See J. MASHAw \& D. HARFsT, supra note 1, at 95-103.

38. See, e.g., Shapiro, APA: Past, Present and Future, 72 VA. L. Rev. 447 (1986) (arguing that court demands for synoptic rationality in administrative decisionmaking reflect a judicial preference for the status quo).

39. See J. MAShaw \& D. HARFst, supra note 1, at 147-201. 
concerning air pollution control regulation, ${ }^{40}$ which are echoed by John Mendeloff's work on Occupational Safety and Health (OSHA) regulation $^{41}$ and Dick Pierce's recent analysis of the looming electric power crisis.42 Moving out of the domain of regulation by rule, the dysfunctional pohicy effects of judicial review of adininistrative action have been traced in welfare administration, ${ }^{43}$ disability benefits adjudication, ${ }^{44}$ labor law, ${ }^{45}$ prison management, ${ }^{46}$ public education, ${ }^{47}$ and elsewhere. ${ }^{48}$

To be sure, this chorus of complaint about judicial review is controversial. The dynamics of administrative action are too complex to place enormous confidence in any ascription of causal efficacy-or, in these studies, causes of inefficacy-however sophisticated the analysis. Yet the puzzle remains. Why does Chris Edley place so much stock in judicial salvation? As I recall the recent past of administrative law, there is substantial evidence that judicial action is inherently conservative in its conceptual content and often dysfunctional to the point of destruction with respect to legislative and administrative attempts to construct innovative regulatory policy.

\section{SUNSTEIN’s Substance}

Cass Sunstein is as unhappy with American administrative law as is Chris Edley, but for quite different reasons. In Sunstein's view, we have been so fixated on "procedure" and "judicial review" that we iguore programmatic substance. ${ }^{49}$ What we need, he claims, is a set of interpretive priniciples that will assist legislators and administrators in the task of programmatic and institutional desigu, and that will guide courts in helping administrators evade the multiple maladies that afflict administrative systen1s. ${ }^{50}$ (1983).

40. See S. Melnick, Regulation and the Courts: The Case of the Clean Air Act

41. See J. Mendeloff, The Dilemma of Toxic Substance Regulation (1988).

42. See Pierce, The Unintended Effects of Judicial Review of Agency Rules: How Federal Courts Have Contributed to the Electricity Crisis of the 1990s, 43 ADMIN. L. REV. 7 (1991). (1983).

43. See Simon, Legality, Bureaucracy, and Class in the Welfare System, 92 YALE L.J. 1198

44. See J. Mashaw, Bureaucratic Justice: Managing Social Security Disability Claims 187-88 (1983).

45. See Winter, Judicial Review of Agency Decisions: The Labor Board and the Court, 1968 Sup. CT. Rev. 53.

46. See J. Jacobs, Stateville: The Penitentiary in Mass Society (1977).

47. See D. Horowitz, The Courts and Social Policy (1977).

48. See Glazer, Should Judges Administer Social Services?, 50 PUB. INTEREST 64 (1978).

49. See Sunstein, Administrative Substance, 1991 DUKE L.J. 607, 611.

50. See id. at 631-42. 
Sunstein's argument restates in trenchant form most of his recent claims about why an activist regulatory state is a good thing and why it has characteristic failures or dysfunctions. ${ }^{51}$ I find much of this discussion unobjectionable. Nevertheless, Sunstein's tendency to place greater reliance on social science findings than they will bear, and his apparent belief that the "substance" argued for in one regulatory domain is transportable to another with equally salutary effects, ${ }^{52}$ give me considerable cause to doubt the efficacy of his reform prograin.

The latter tendency in particular suggests that Sunstein is remembering the future. Like the military that finds itself well-equipped to fight the last war but woefully unprepared to fight the next one, reform programs built on this sort of foundation may find themselves unready for a different set of tactical or strategic challenges. I will illustrate by reference to Sunstein's principal reform proposal-the replacement of regulatory commands with economic incentives. ${ }^{53}$ First, I will consider the question of the generalizability of the major substantive proposition Sunstein puts forward for a reconstructed administrative law. Second, I will return to the question of how a substantive administrative law is to be grounded. Finally, I will look at whether a move toward "substance," in the sense that Sunstem einploys that tern, is indeed the right agenda for adıninistrative law scholarship.

\section{A. The Case for Incentives}

Sunstein argues quite forcefully that command-and-control regulation in the environmental arena has had soine unhappy consequences. ${ }^{54}$ Moreover, it is plausible that greater use of economic incentives would promote more environmental protection at lower economic cost and with a greater sense of the fairness and legitiniacy of the regulatory process. Sunstein is, of course, hardly alone, or even early, in promoting these reforıns in the environmental arena or in other domains of "social regulation." 55 His distinctive contribution is to emphasize the gains that may flow from market-like incentives in more than purely economic terns.

51. See, e.g., Sunstein, Changing Conceptions of Administration, 1987 B.Y.U. L. REV. 927; Sunstein, Interpreting Statutes in the Regulatory State, 103 HARV. L. REV. 405 (1989); Sunstein, Of the Costs and Benefits of Aggressive Judicial Review of Agency Action, 1989 DukE L.J. 522 (1989); Sunstein, Paradoxes of the Regulatory State, 57 U. CHI. L. REV. 407 (1990).

52. See Sunstein, supra note 49 , at 634-42 (advocating the nse of market-based incentives in environmental, occupational safety and health, and other areas).

53. See id. at 631-34.

54. See id. at 625 .

55. See, e.g., Crandall, Why Should We Regulate Fuel Economy at All?, 3 BRookIngs REv. 3 (1985) (arguing that Corporate Average Fuel Economy's (CAFE) original purposes are outmoded in light of recent developments); R. CRANDALl, H. GRUENSPECHT, T. KEELER \& L. LAVE, RegULATING THE AUTOMOBILE 117-40 (1986) (arguing that it is unclear whether regulation of fuel econ- 
Although I agree that incentive systems have some excellent political properties and that their distributional difficulties are often oversold, I am much less sanguine than he concerning the political feasibility and regulatory efficacy of substituting pricing for controls in many regulatory environments. Let me say but a few words about political feasibility and provide a somewhat more extended discussion of the problem of regulatory efficacy.

Pohitical feasibility has at least two dimensions. The first is simply practical politics. For example, although I agree with Sunstein that a gasoline tax is vastly superior to Corporate Average Fuel Economy (CAFE) regulation, Congress remains steadfast in its pohitical cowardice. It insists on a regulatory regime that identifies automobile companies (rather than American drivers) as both the perpetrators of crimes against conservation and as the ones who will pay the price of their profligate ways.

The second feasibility issue has to do with pohitical symbolism. For example, a very strong case can be made for exphicit, workforce-based quotas combimed with free trade in "excess minority hires" to solve the continued maldistribution of employment opportumities for minorities. ${ }^{56}$ Yet there is very hittle chance that such a scheme would be adopted; not only is no pohtician willing to be associated with the " $Q$ word," the prospect of trading "discrimination rights" has, if anything, an even less happy symbohic quality than trading "pollution rights." Emissions tradmg seems finally to have surmounted the charge that it makes environmental regulation into a "license to pollute." But this success cannot negate the reality that the market often produces negative as well as positive pohitical symbohsm. Those negative features will often dissuade legislators from its use.

Perhaps even more importantly, market-like tecliniques have more himited regulatory capacities than inight appear at first glance. In many circumstances (for example, the emissions trading case itself), the market can allocate regulatory costs, but not set regulatory goals. Environmental standards must still be set by command. There is talk of "pollution taxes," of course, in addition to emissions trading as incentive devices, but here too the level of the tax sets an implicit (and probably inexact)

omy has had an impact that would not have otherwise occurred due to outside forces such as a rise in gasoline prices).

56. See Mashaw, Implementing Quotas, 79 GEO. L.J. 1769 (1991) (arguing that "discrimination trading" would be an essential implementing strategy for such a scheme); Strauss, The Law and Economics of Racial Discrimination in Employment: The Case for Numerical Standards, 79 GEo. L.J. 1619 (1991) (arguing for explicit national quotas as a substitute for current non-discrimination policy). 
level of environmental quality. "The market" does not decide the appropriate level of environmental quality in these schemes; it instead only allocates clean-up duties to those who can do so at the lowest cost. This is no small gain, but we should not be lured into thinking that the use of incentives avoids all the hard pohtical choices involved in compelling the production of environmental non-degradation in place of other goods and services that an unregulated market would provide. ${ }^{57}$

Consider an initial question: Why should we have autoinobile safety regulation that attempts to reshape automotive technology to produce a safer car? At first blush the idea is an odd one. After all, automobiles are bought and sold in highly competitive markets-markets that overflow with good information. If consumers want safer cars, then their demand in the marketplace will lead manufacturers to respond with supply. Indeed, there has long been a miche at the high end of the market for cars that emphasized their capacity to avoid crashes and to protect their occupants should accidents occur. ${ }^{58}$ Sunstein's admonition to use market incentives would here seem to support complete deregulation.

But not so fast. Our superficial examination may miss subtle forms of market failure that cannot be corrected by a return to the market, or to market-like incentives. The most general is a concern with preference formation. Perhaps we want to desire safer cars, but we are all too susceptible to acting out other aspects of our personalities-demands for power, status, and luxury-once we enter the dealer's showroom. If so, it might make sense, as Cass Sunstein has himself so eloquently argued,59 to impose some safety discipline on ourselves by regulation. 60

But it is not just symbohic or educative inappropriateness that sometimies counsels against using market incentives to shape behavior. In some cases, markets cannot be organized effectively. This problem attends the other, more straightforward, inarket failure that might be thought to beset the expression of consumer preferences for safer cars. The story goes something like this: In a third-party liability system,

57. Even more dramatically, market incentives may be impossible to structure into many regulatory schemes. For example, in the motor vehicle safety arena, the problems of technical infeasibility combine with issues of political economy and political symbolism to make an otherwise sensible market strategy a virtual impossibility. But this gets ahead of the story.

58. Volvo, for example, has long advertised the safety of its automobiles.

59. See Sunstein, Preferences and Politics, 20 PHIL. \& PUB. AFF. (forthcoming 1991); see also authorities cited in Sunstein, supra note 49 , at notes $54-58$ and accompanying text.

60. I hasten to add that I am not fully persuaded by the case for self-paternalism, for I have no idea how to make the real "us" stand up. As sages from Pogo to Bruce Ackerman remind us, "we the people" seems to shift our characters along with shifts in decisional contexts. See B. ACKERMAN, We the PeOple: Foundations 105-62, 230-66 (1991). Yet, it would not be silly to imagine that, here and elsewhere, we might use regulation-and eschew the market-to shape our tastes in (sometimes) desired directions. 
where the party at fault pays for all the damage, the automobile buyer does not reap all the rewards of buying a safer car. In fact, some of the benefits go to the party charged with compensating the occupants of the safer vehicles. Conversely, if the purchaser were the insurer of all damage occurring to or in his or her automobile, then the benefits of buying a safer car would remam with the buyer. Universal first-party insurance, or "no-fault insurance," produces this internalization of benefits. Under a no-fault scheine, insurers make premiums dependent in part on the safety of the insured's automobile. In this way, the savings from insurance costs are an incentive for drivers to demand, and consequently manufacturers to produce, safer vehicles.

No-fault insurance champions have been around for years, ${ }^{61}$ and several states have adopted some version of no-fault hability. ${ }^{62}$ Lower hitigation costs and faster compensation have driven these schemes. That the costs and benefits of vehicle safety correlate with consumer demand for vehicle safety makes no-fault even more attractive. Civil liability reform and vehicle safety regulation are combined in such a scheme.

Unfortunately, no-fault insurance cannot serve as a complete strategy for automobile safety improvernent. The principal problem is that insurance coinpanies may well be unable to experience-rate the safety of automobiles on the basis of actual road experience. The necessary data are unavailable at the time of the purchase and initial insurance on new cars. Thus, the scheme would work only if cars maintained the same safety characteristics over substantial time periods. New models would need to be evaluated on the basis of data collected on older models.

However, the safety characteristics of car models are not constant. Consumer Reports, which analyzes NHTSA's crash tests, repeatedly warns that even minor annual changes in a car model can significantly affect its crashworthiness. ${ }^{63}$ Models that perform well one year may perform poorly the next. In addition, NHTSA's analyses of crash data often do not agree with the analyses done by insurance companies. The data are simply not good enough to permit a fine-grained determination of the likely safety experience of new cars at the point of sale.

61. The classic work is R. Keeton \& J. O'ConnelL, Basic Protection for the Traffic VICTIM (1965).

62. E.g., Fla. Stat. ANN. § 627.727 (West 1984 \& Supp. 1991); Kansas Automobile Injury Reparations Act, KAN. STAT. ANN. §§ 40-3101 to -3121 (1986 \& Supp. 1990); New Jersey Automobile Reparation Reform Act, N.J. STAT. ANN. §§ 39:6A-1 to :6A-35 (West 1990 \& Supp. 1991); Comprehensive Motor Vehicle Insurance Reparations Act, N.Y. INs. LAw \$§ 5101-5108 (McKinney 1985 \& Supp. 1991); Motor Vehicle Personal and Property Protection Act, Mich. CoMP. Laws ANN. $\S 500.3101-3179$ (West 1983 \& Supp. 1991).

63. See Which Cars Do Best in a Crash?, Consumer ReP., April 1991, at 219, 221. 
Despite these doubts about the efficiency of no-fault insurance, some safety improvements are consistent with such a scheme. Dramatically safer technologies, such as the air bag, can be promoted. Moreover, implementation via no-fault insurance has advantages over NHTSA-style rulemaking. The latter encounters several legal and pohtical problems that Harfst and I review in our book: a wavering political commitment in Congress; dilatory executive inonitoring; a constitutional skepticisin about administrative rulemaking that is expressed through judicial review; inforination advantages of the regulated industry; concerns about domestic competitiveness and autoworkers' unemployment; an ambivalent public; and extreıne variations in different administrations' comınitments to vehicle safety. ${ }^{64}$ By contrast, a no-fault system exerts decentralized economic pressure to improve vehicle safety on parties responsive to such incentives. Finally, and perhaps most significantly, the automobile, an American symbol of individual autonomy, would be symbolically unshackled from government mandates. The American freedom machine would once again be free.

But before jumping to the conclusion that, with better data and forecasting, no-fault insurance is a motor vehicle safety panacea, think about getting there from here. In short, reconsider politics. What syinbols can be used to proniote this general deterrence strategy and to what public values will they appeal? Safety and public liealth are always available as slogans, as are the claims of faster and more efficient compensation. Such a legislative campaign may even utilize the catchword "privatization"- a rejection of centralized bureaucracy in favor of claimant-activated civil justice and consumer-oriented market incentives.

Nevertheless, it is doubtful that many will flock to these banners. Opposing forces will likely counter with themes of "justice"-no-fault regimes do not pernnit compensation for pain and suffering. Additionally, no-fault programs must either be promoted state-by-state, or pursued nationally, thus confronting the states rights ideology that has historically defended state control of tort law and insurance regulation. In short, either strategy seems dooined.

Notwithstanding the social advantages of no-fault insurance, the experience of this scheine in the United States suggests that defenders of the status quo have a decided political advantage. No major organized economic interest anticipates gains from a shift to no-fault. The insurance companies lose if the scheme reduces accident costs. Overall levels of coinpensable loss shrink by the elimination of noneconomic losses. In fact, even if accident rates are unaffected, casualty insurance premiums

64. See J. MAShaw \& D. HARFst, supra note 1, at 242-43. 
and associated investment income decline. The insurance industry also will see this as the first step toward federal regulation of the entire imdustry. Other powerful groups, such as the American Trial Lawyer's Association, will join the fight in opposing no-fault.

This is not to say that well-devised no-fault insurance proposals have no prospect for legislative adoption. A similar appraisal in 1966 would not have predicted the passage of the MVSA. But there is some very rough political sledding here. When combined with doubts about efficacy in action, the political economy of the enactment of universal nofault insurance makes rehiance on that strategy deeply problematic.

To summarize, the question of what works-or as Sunstein frames it, the question of wliat the substantive provisions of administrative law should look like ${ }^{65}$-is not easily approachable in general terms. If Sunstem's preference for market incentives is only a rule of thumb that encourages policymakers to experiment witli such systeins, and judges to permit that experimentation where not precluded by statute, then the position is unobjectionable. But it is not mucli of a reform program. This preference describes the thrust of administration policies from Carter to Bush, as well as the legal environment enshrined in Chevron. That we are not moving more quickly toward this particular substantive goal suggests the intrusion of "feasibility" problems of the sort exemplified by the motor vehicle safety discussion. ${ }^{66}$

Moreover, a more contextualized approach to substantive analysis reveals the difficulties of using substantive presumptions in some stronger form. The "findings" of the political-economy scliolarslip on which inore generalized presumptions might be based are weak, and unless one is prepared to ground some presuppositions about appropriate regulatory form normatively, rather than positively, it may be very difficult to construct a useful or "valid" substantive administrative law-as distinguished from a useful or valid environmental law, labor law, cominurications law, and so on. This is, of course, the presupposition of the conventional, "proceduralized" administrative law of which Sunstein complaims.

His complaimt has been made by others, and it is hardly witlout merit. As one observes the ceaseless wrangling in decided cases concerning the miceties of administrative hearings and the "procedural rationality" of agency policy choices, adninistrative law does seen to exhibit a sure instinct for the capillary. So much loopla about so hittle of apparent

65. See Sunstein, supra note 49 , at $611-22$.

66. See supra text accompanying notes 35-37. 
substantive moment. Yet, I wonder whether the complaint is not overdrawn in two senses.

First, the notion that administrative law lacks substantive commitments is simply false. As a subfield of constitutional law, administrative law has strong and continuous normative commitinents to procedural fairness, decisional transparency, and admimistrative accountability. ${ }^{67}$ These are administrative law's distinctive einbodiments of a inore general liberal, democratic ideological agenda that supports individual autonomy and civic equality through precisely those structures of eighteenth-century legal thought that provoke Chris Edley's critique. Indced, unless that "substance" of administrative law existed-in however coinpromised and tortured a form one takes it to have achieved over these last two hundred years-Edley's arguments would be unintelligible.

Second, Sunstein's critique of substantive emptiness ironically equates administrative law with judicial review, while simultaneously urging that administrative law's contmued focus on judicial review is the inyopia to be avoided. If one looks at legislative and administrative (rather than judicial) action, it is difficult to avoid concluding that significant substantive innovation is constantly occurring. The 1970 s and 1980s saw niajor revolutions in the legislatively-provided structures and mandates of administrative regulatory agencies, ${ }^{68}$ continuous legislative attention to issues of administrative openness, ${ }^{69}$ and major executive branch initiatives to proinote the evaluation of regulatory alternatives in

67. Once again, this point has been inade by Sunstein elsewhere. See Sunstein, Factions, SelfInterest, and the APA: Four Lessons Since 1946, 72 VA. L. REV. 271 (1986).

68. See, e.g., S. Melnick, supra note 40, at 5-9 (1983) (describing the purpose, scope, and structure of the "new regulation"); see also J. MASHAw \& D. HARFST, supra note 1, at 1-7 (describing how the MVSA "should be seen as creating the first of a new breed of federal regulatory agencies ... concerned with health and safety").

69. See, e.g., Freedon of Information Act, 5 U.S.C. § 552 (1988); Privacy Act, id. § 552a; Governınent in the Sunshine Act, id. § 552b; Federal Advisory Colnmittee Act, id. app. at 1175-83. Multiple amendments have been made to these statutes during the last two decades. For the Freedom of Information Act amendments, see Act of June 5, 1967, Pub. L. No. 90-23, § 1, 81 Stat. 54; Act of Nov. 21, 1974, Pub. L. No. 93-502, \$§ 1-3, 88 Stat. 1561-64; Act of Sept. 13, 1976, Pub. L. No. 94-409, §5(b), 90 Stat. 1247; Act of Oct. 13, 1978, Pub. L. No. 95-454, § 906(a)(10), 92 Stat. 1225; Act of Nov. 8, 1984, Pub. L. No. 98-620, § 402(2), 98 Stat. 3357; Act of Oct. 27, 1986, Pub. L. No. 99-570, §§ 1802-1803, 100 Stat. 3207-48, 3207-49. For the Privacy Act amendinents, see Act of Dec. 31, 1975, Pub. L. No. 94-183, § 2(2), 89 Stat. 1057; Act of Oct. 25, 1982, Pub. L. No. 97-365, $\S 2$, 96 Stat. 1749; Act of Dec. 21, 1982, Pub. L. No. 97-375, § 201(a)-(b), 96 Stat. 1821; Act of Jan. 12, 1983, Pub. L. No. 97-452, § 2(a)(1), 96 Stat. 2478; Act of Oct. 15, 1984, Pub. L. No. 98-497, $\S 107(\mathrm{~g}), 98$ Stat. 2292; Act of Oct. 18, 1988, Pub. L. No. 100-503, §§ 2-6(a), 7, 8, 102 Stat. 2507-14; Act of Nov. 5, 1990, Pub. L. No. 101-508, § 7201(b)(1), 104 Stat. 1388. There have been no amendments to the Government iu the Sunshine Act. For the Federal Advisory Committee Act amendments, see Act of Sept. 13, 1976, Pub. L. No. 94-409, § 5(c), 90 Stat. 1247; Act of Dee. 21, 1982, Pub. L. No. 97-375, § 201(c), 96 Stat. 1822. 
cost-benefit or cost-effectiveness terms. ${ }^{70}$ The causes and cures of "regulatory failure" are being addressed in the adininistrative law created by both Congress and the Executive Branch, however laggard the judiciary inay be in this regard.

\section{CONCLUSION}

It inay well be true, as Chris Edley suggests, that adninistrative law agonizes about its content and its future inore than other fields. But, if so, I would argue that this public teeth-gnashing is evidence more of its students' and practitioners' openness to new ideas than of its nitellectual bankruptcy. Administrative law has a core in exactly the same sense as torts, contracts, or any other najor legal doniam-a set of general propositions that take on life and meaning only as apphed in particular contexts. Therefore, it is as open (but not more open) to the charge that because understanding context is iniperative, the core concepts nust either be irrelevant or incoherent.

In my view, the special failure of adıninistrative law scholarship lies neither in its failure to take ideological substance seriously (as Edley charges) nor in its focus on inatters of imstitutional and procedural design (as im Sunstein's account). Rather, its failure is its inability to make explicit the continuous and necessary oscillation between inatters of principle and inatters of implenientation, that is, between general normative cominitments and the concrete necessities of governance in particular contexts. As Edley and Sunstein argue, adıninistrative law niay need a stronger defense of its ideological prenises and greater attention to both the particular and the inore general political, economic, and technological contexts of its apphication. But the deeper need is sonewhat different. We need a better way of talking about the refraction of premises through contexts, and contexts through premises. That is where the real law hives, grows, and hides. ${ }^{71}$ Otherwise, as we try to remember the real past and imagine the possible future we will be too easily nuesmerized, and then frustrated, by doctrinal epiphenoinena.

70. These executive initiatives begin with the "quality of life review" program in the Office of Management and Budget during the Nixon Administration and carry on through increasingly stringent requirements embodied in Executive Orders by Presidents Ford (Exec. Order No. 11,821, 3 C.F.R. $\$ 926$ (1975)), Carter (Exec. Order No. 12,044, 3 C.F.R. $\$ 152$ (1978)), and Reagan (Exec. Order No. 12,291, 46 Fed. Reg. 13,193 (1981), reprinted in 5 U.S.C. $§ 601$ note (1988); Exec. Order No. 12,498, 50 Fed. Reg. 1036 (1985), reprinted in 5 U.S.C. $\S 601$ note (1988)).

71. See generally J. MASHAW, supra note 44, at 15 (My attempt to develop an "internal law of administration."). For a provocative discussion of the necessity of broadening the focus of administrative law teaching and scholarship, see Schotland, "How Much Truth Is Too Much Truth for Judicial Review?" and Other Easy Pieces After an AALS Workshop on Teaching Administrative Law, 43 ADMIN. L. REV. 113 (1991). 